\title{
Private international law and EU external relations: Think local act global, or think global act local?
}

\author{
Alex Mills* \\ Forthcoming, International and Comparative Law Quarterly (2016) \\ Author's final manuscript, March 2016
}

\begin{abstract}
In the European Union, private international law has almost exclusively been developed through the adoption of internal acts (particularly EU Regulations) in the pursuit of internal goals (principally, enhancing the efficient functioning of the internal market, and more recently and broadly the construction of an area of freedom, security and justice). This focus has and must come under challenge in light of two developments. The first is the apparent establishment of EU exclusive external competence in the field of private international law, creating the opportunity for external action by the EU. The second is the increased recognition that internal action by the EU has external effects, which should be viewed not merely as incidental but also as potentially instruments of external policy. In conjunction, these developments demand consideration of what role private international law could and should play as part of EU external relations. This article critically examines a range of possible techniques which might be adopted in relation to this new external dimension of EU private international law. These methods are not necessarily unique to private international law or the EU, and thus this article also provides a case study of the range of legal techniques which can be used by international actors to project policies externally.
\end{abstract}

\section{Introduction}

In the European Union, private international law has almost exclusively been developed through the adoption of internal acts (particularly EU Regulations) in the pursuit of internal goals (principally, enhancing the efficient functioning of the internal market, and more recently and broadly the construction of an area of freedom, security and justice). ${ }^{1}$ This article analyses the policy options open to the EU in terms of the 'external' dimension of private international law, looking at the potential role of private international law in EU external relations. While it is focused entirely on EU private international law, the methods examined are not necessarily unique to private international law or the EU, and thus this article also presents a case study of the range of

\footnotetext{
${ }^{*}$ Reader in Public and Private International Law, Faculty of Laws, UCL, a.mills@ucl.ac.uk. An early version of this article was presented at a conference at the University of Ferrara in February 2015, and thanks go to Pietro Franzina and the other organisers of and participants in that conference, and to Piet Eeckhout and Joanne Scott for comments on a later draft.

1 Articles 67(1) and 81(2), Consolidated version of the Treaty on the Functioning of the European Union (2012) OJ C 326/47, 26 October 2012 (henceforth, TFEU). See infra n 39 and n 84.
} 
legal techniques which can be used by international actors to project policies extraterritorially. There are, however, two main justifications for providing this analysis in relation to EU private international law in particular, which correspond with two distinct aspects of the analysis presented in this article.

First, in Opinion 1/13, a Grand Chamber decision issued on 14 October 2014, the European Court of Justice confirmed that the European Union has exclusive external competence in the field of private international law, at least in subject areas in which the EU has exercised internal competence. While this Opinion related specifically to civil aspects of international child abduction, the logic of the Opinion is (as argued in section II below) just as (if not more) forcefully applicable in the general field of civil and commercial disputes covered by the Brussels I Regulation (in relation to jurisdiction and the recognition and enforcement of judgments) and the Rome I and II Regulations (in relation to choice of law in contractual and non-contractual obligations). If it is accepted that the EU has a broad exclusive external competence in this field, the next question which arises is: what (if anything) should the EU do with this competence? Should the EU now pursue its internal goals externally (aiming to increase the efficiency of the 'external' market, or to extend the area of freedom, security and justice beyond the boundaries of the EU), or should it simply use its external competence as a further means to pursue these goals internally, or should it pursue other goals altogether?

Second, it has become increasingly recognised that the internal rules of private international law adopted in the EU may themselves have 'external' effects through their impact on disputes or relationships which have connections with non-Member States. These external effects have traditionally tended to be viewed as marginal or incidental because of the focus on internal policy goals in the development of EU private international law, but it will be argued that they are themselves potentially significant. Understanding these effects opens up the possibility of using them intentionally through careful design of private international law rules and exceptions. For example, the EU might use private international law as a means of projecting policies extraterritorially by limiting access to EU recognition unless a foreign law or judgment complies with certain standards - a regulatory technique used (somewhat controversially) by the EU in other contexts such as trade and environmental law. ${ }^{2}$ Even the exercise of internal competence thus involves the same policy questions and concerns noted above - while this exercise should of course be primarily addressed to internal policy goals, it must also be asked what external policy goals could or should the EU aim to achieve through the external effects of its internal rules of private international law?

In summary, there are a variety of possible external policies which the EU might pursue through private international law - a range of potential purposes for which private international law may be used. This could involve 'acting globally', through participation in the development of international law governing rules of private international law (as explored in section III below), or it could involve 'acting locally', through the

\footnotetext{
${ }^{2}$ See further section IV.B below.
} 
development of EU private international law rules with targeted external effects (as explored in section IV below). Each of these deserves careful analysis and consideration.

\section{EU external competence in private international law}

It has become increasingly difficult to resist the contention that the European Union has exclusive external competence in at least most of the field of private international law. The principle has long been laid down that exclusive external competence for the EU may be derived from the exercise of internal competence, where the (potential or actual) external rules 'are of such a kind as to affect the Community rules'. ${ }^{3}$ This is the case even if those external rules are not directly inconsistent with Community (now European Union) rules, but merely diminish uniformity by going further than those rules. ${ }^{4}$ The ECJ has emphasised, in fact precisely in the field of private international law (but setting out a rule which is applicable more generally), that for external competence to arise, all that is necessary is that the conclusion of an international agreement is capable of affecting the Community rules. ${ }^{5}$ For this to be the case, 'it is not necessary for the areas covered by the international agreement and the Community legislation to coincide fully'6; 'the assessment must be based not only on the scope of the rules in question but also on their nature and content'; and '[i]t is also necessary to take into account not only the current state of Community law in the area in question but also its future development, insofar as that is foreseeable at the time of that analysis'. ${ }^{8}$

These principles have now been partially codified in the Treaty on the Functioning of the European Union, Article 3(2) of which provides (in relevant part) that:

The Union shall also have exclusive competence for the conclusion of an international agreement ... in so far as its conclusion may affect common rules or alter their scope. ${ }^{?}$

Article 3(2) has recently been analysed by the ECJ in two decisions, each of which has confirmed that the earlier case law continues to be relevant to its interpretation.

\footnotetext{
${ }^{3}$ ECJ Opinion 2/91 on Convention No 170 of the International Labour Organization concerning safety in the use of chemicals at work, at [26]; developing the principle established earlier in Commission v Council ('ERTA Case') (1971) ECR 263, Case 22/70. See generally Geert de Baere, 'Constitutional Principles of EU External Relations' (Oxford University Press, 2008), p.43ff; Piet Eeckhout, 'EU External Relations Law' (Oxford University Press, $2^{\text {nd }}$ edition, 2011), p.70ff.

${ }^{4}$ ECJ Opinion 2/91, at [25], noting that 'there is no contradiction between these provisions of the Convention and those of the directives mentioned'.

5 ECJ Opinion 1/03 on the Competence of the Community to conclude the new Lugano Convention on jurisdiction and the recognition and enforcement of judgments in civil and commercial matters (henceforth, 'Lugano Opinion'), at [124]. See generally Fausto Pocar (ed), 'The External Competence of the European Union and Private International Law: The EC Court's Opinion on the Lugano Convention' (Wolters Kluwer Italia, 2007).

${ }^{6}$ Ibid., at [126].

7 Ibid.

${ }^{8}$ Ibid.

${ }^{9}$ Article 3(2), TFEU.
} 
First, in relation to the negotiation of an international agreement relating to broadcasting rights, the ECJ emphasised that exclusive external competence is justified by 'a risk that common EU rules might be adversely affected by international commitments, or that the scope of those rules might be altered'10, which 'does not presuppose that the areas covered by the international commitments and those covered by the EU rules coincide fully'11, but may arise 'within an area which is already largely covered by such rules',12 even if 'there is no possible contradiction between [potential Member State] commitments and the common EU rules'. ${ }^{13}$

The second case in which Article 3(2) of the TFEU has recently been interpreted by the ECJ is Opinion 1/13, which directly relates to the field of private international law. The Court held that the EU must have exclusive competence to decide whether to accept the accession of a third state (a non-EU Member State) to the 1980 Hague Convention on the civil aspects of international child abduction, otherwise 'there would be a risk of undermining the uniform and consistent application'14 of the Brussels IIbis Regulation. ${ }^{15}$ Pursuant to this decision, the EU has recently exercised this competence by authorising certain Member States to accept the accession of Singapore and Andorra to the Convention. ${ }^{16}$

These developments in the rules governing EU exclusive competence are controversial, both legally and politically. But on the basis of these authorities, there is a clear case that the EU must have exclusive external competence in other areas of private international law. ${ }^{17}$ In the context of jurisdiction and the recognition and enforcement of judgments, for example, at present the EU rules set out in the Brussels I Regulation ${ }^{18}$ do not (generally ${ }^{19}$ ) govern jurisdiction regarding claims against non-Member State defendants or the recognition and enforcement of non-Member State judgments. Those matters are left

\footnotetext{
${ }^{10}$ Commission v Council (Judgment) [2014] EUECJ C-114/12 (04 September 2014), at [68].

${ }^{11}$ Ibid., at [69].

12 Ibid., at [70].

${ }^{13}$ Ibid., at [71].

${ }^{14}$ ECJ Opinion 1/13 (14 October 2014), at [89].

15 Council Regulation (EC) No 2201/2003 of 27 November 2003 concerning jurisdiction and the recognition and enforcement of judgments in matrimonial matters and the matters of parental responsibility, OJ L 338/1, 23 December 2003.

${ }_{16}$ Council Decisions 8933/15 and 8935/15, 5 June 2015. Somewhat controversially (at least in the sense that the European Commission issued a statement objecting), the decision only applies on behalf of those Member States which had not previously indicated (unilaterally) their acceptance of Singapore and Andorra's accession to the Convention, even though the ECJ concluded that such acts by Member States were contrary to EU law. The basis for this approach is presumably (and as suggested by Recital 12 of the Decision) a concern that such acts, even if invalid as a matter of EU law, might nevertheless have been valid as a matter of public international law, as this limitation on the competence of Member States was not 'objectively evident' prior to ECJ Opinion 1/13 - see Article 46 of the Vienna Convention on the Law of Treaties (1969).

17 On this issue, see generally Pocar (2007), supra $n 5$.

18 Most recently, Regulation (EU) No 1215/2012 of the European Parliament and of the Council of 12 December 2012 on jurisdiction and the recognition and enforcement of judgments in civil and commercial matters (recast), OJ L 351/1, 20 December 2012 (henceforth, 'Recast Brussels I Regulation 2012').

${ }^{19}$ With the exception of the rules on exclusive jurisdiction under Articles 24 and 25 . Article 26 does not clearly state whether it applies regardless of the domicile of the defendant, but (although the point is somewhat debated) its omission from mention in Article 6 would suggest that it does not. See further eg James Fawcett and Janeen M. Carruthers, 'Cheshire, North and Fawcett Private International Law' (Oxford University Press, 14th edn, 2008), at p.297.
} 
to national law, and can evidently be amended by national law-making bodies, and so it might be thought that Member States could equally enter into international agreements which affected only these national rules. Although the ECJ already held in 2006 that the EU had exclusive competence to enter into the Lugano Convention, as noted above, ${ }^{20}$ that might be considered a special case as that Convention was intended to extend the systemic effects of the Brussels I Regulation, ${ }^{21}$ which would not necessarily be the case for other private international law agreements. However, it is evident that any such exercise of external competence would have an impact on the scope of obligations under the Brussels I Regulation (even more so now under the Recast Brussels I Regulation $2012^{22}$ than under the Brussels I Regulation 200123), in three major ways.

First, under the Recast Brussels I Regulation 2012 (as under the Brussels I Regulation 2001) Member States are under an obligation to recognise and enforce judgments from other Member States, subject to limited safeguards or defences. That obligation applies irrespective of whether the judgment court took jurisdiction based on the Brussels I Regulation rules or based on its residual national rules of jurisdiction, ${ }^{24}$ and the jurisdiction of the judgment Court may not be questioned (except for disputes concerning subject matter which attracts exclusive jurisdiction under the Regulation ${ }^{25}$ ). (As discussed further below, this has the well-known and curious side effect that those national rules of jurisdiction have been made more powerful under the Regulation, to the significant disadvantage of non-EU domiciled parties. ${ }^{26}$ ) As a consequence, the national rules of jurisdiction of each Member State directly affect the 'scope' of the obligations of each other Member State. For example, any change in the French national rules of jurisdiction governing claims against non-EU domiciled parties (which might be required if, for example, France entered into an international convention with the home state of such parties) would affect the 'scope' of UK obligations (under EU law) to recognise and enforce French judgments. The argument here is not that the obligation itself would change, but that the extent, meaning or content of the obligation would be affected, because it is dependent on elements of national law which could be altered through an international commitment entered into by an individual Member State. As discussed above, ${ }^{27}$ the ECJ has held that it is sufficient that the 'scope' of an EU law obligation be

\footnotetext{
20 Supra n 5.

${ }^{21}$ See the Lugano Opinion, supra n 5, at [152]ff.

22 Supra $\mathrm{n} 18$.

${ }^{23}$ Council Regulation (EC) No 44/2001 of 22 December 2000 on jurisdiction and the recognition and enforcement of judgments in civil and commercial matters, OJ L 12/1, 16 January 2001 (henceforth, 'Brussels I Regulation $\left.2001^{\prime}\right)$.

${ }^{24}$ See further eg Fawcett and Carruthers (2008), supra n 19, at p.224, p.599; this is now set out in Recital 27 of the Recast Brussels I Regulation 2012.

${ }^{25}$ See Article 45(1)(e)(ii). This does not, however, appear to permit a defence to be raised if the claim has equivalent connections with non-Member States - a French judgment concerning title to New York immovable property would apparently be enforceable in the English courts. This phenomenon follows from the lack of consideration of connections with non-Member States under the jurisdictional rules, a problem highlighted in section IV.A below although if the rules of subject matter exclusive jurisdiction are given reflexive effect, the problem should not arise in practice.

26 See further eg Arthur Taylor von Mehren, 'Recognition and Enforcement of Sister-State Judgments: Reflections on General Theory and Current Practice in the European Economic Community and the United States' (1981) 81 Columbia Law Review 1044; Koji Takahashi, 'Review of the Brussels I Regulation: A Comment from the Perspectives of Non-Member States (Third States)' (2012) 8 Journal of Private International Law 1.

${ }^{27}$ See supra n 10.
} 
affected (or potentially affected) by international commitments for the matter to fall within the exclusive competence of the EU, even if no possible contradiction can arise between those international commitments and EU law. ${ }^{28}$

Second, a similar effect arises in relation to the rules on lis pendens. Under the Regulation, courts are obliged to stay proceedings if they are second seised of a dispute already before the courts of another Member State, and permitted to stay proceedings if they are second seised of a dispute related to one already before the courts of another Member State, regardless of the basis of jurisdiction under which either court is seised. ${ }^{29}$ If French national rules of jurisdiction were changed, this would, for example, also change the scope of the obligation of the English courts to finally decline jurisdiction because the English courts are second seised of a dispute and the court first seised has established its jurisdiction. ${ }^{30}$

Third, a further distinct issue arises under the 2012 Recast Regulation in relation to the rules on recognition and enforcement of judgments. Articles 33 and 34 of the 2012 Recast Regulation introduced new rules which govern lis pendens issues arising in relation to non-Member State proceedings, giving the courts of a Member State a discretionary power to stay proceedings where identical or related proceedings are first commenced in a non-Member State. This power only exists where it is expected that the court of the third State will give a judgment capable of recognition and, where applicable, of enforcement in that Member State' 31 - indeed where such a judgment has arisen in the case of identical proceedings, it appears that the discretion is converted to an obligation. ${ }^{32}$ This means that whether a Member State court can (or indeed must) decline jurisdiction under the Regulation depends on the rules of that Member State governing recognition and enforcement of judgments from non-Member States, which are a matter of national law. Any change in those national rules which might arise, for example, through a Member State entering into an international convention with a non-Member State, would affect the scope of that state's powers (and obligations) under the Regulation. (This rule and its effect are clear, even if the justification for the rule is perhaps less so - if the lis pendens rules are aimed at avoiding the risk of parallel proceedings or conflicting judgments, such risks may readily arise even if the judgment of the foreign court is not enforceable in any Member State, particularly where the defendant in the foreign proceedings has assets in that jurisdiction.)

\footnotetext{
28 Although there is room for debate about what 'scope' means or ought to mean in this context, there is an argument that such an extension justifies application of the doctrine of exclusive competence, because it could undermine the perceived legitimacy of EU obligations. For example, if in this context one Member State (perhaps improbably) agreed to a treaty which required it to exercise exorbitant jurisdiction (over claims against non-EU domiciled parties), other Member States might be resistant to enforcing its judgments (as required by EU law) and thereby apparently endorsing its breach of international jurisdictional constraints.

${ }_{29}$ Articles 28-29, Recast Brussels I Regulation 2012; Overseas Union Insurance v New Hampshire Insurance [1991] ECR I3317.

30 Article 29(3), Recast Brussels I Regulation 2012.

31 Article 33(1)(a) and (3), and Article 34(1)(b) and (3).

32 Article 33(3) provides that 'The court of the Member State shall dismiss the proceedings if the proceedings in the court of the third State are concluded and have resulted in a judgment capable of recognition and, where applicable, of enforcement in that Member State.'
} 
On the basis of these three arguments, it appears strongly arguable that the EU must have exclusive external competence in the field of civil and commercial jurisdiction and recognition and enforcement of judgments, as any exercise of external competence by a Member State would affect the scope of the obligations of all the Member States under EU law.

The position is even more evident in relation to questions of choice of law, at least insofar as these fall within the scope of existing EU Regulations including the Rome I Regulation on the law applicable to contractual obligations ${ }^{33}$ and the Rome II Regulation on the law applicable to non-contractual obligations. ${ }^{34}$ Those Regulations are universal in application - they determine the choice of law question in the courts of any Member State regardless of whether the dispute is connected with the European Union, and regardless of whether the governing law is the law of any Member State. ${ }^{35}$ Thus, for example, any treaty entered into by a Member State with a non-Member State which regulated choice of law questions (for contractual or non-contractual obligations) arising in their bilateral relations would directly affect the obligations of the Member State under the Rome I or II Regulations. Applying the principles set down by the ECJ, it follows that the EU must also have exclusive external competence in relation to choice of law questions, at least insofar as these are covered by existing or even potential EU Regulations. This position is indeed reflected in the adoption of a Regulation in 2009, requiring each Member State to obtain the permission of the European Commission before entering into any bilateral or regional agreement relating to matters falling within the scope of the Rome I and II Regulations. ${ }^{36}$ The overall conclusion follows, therefore, that the EU has exclusive external competence in private international law in civil and commercial matters.

If this position is accepted, then the next question which must be asked is: what, if anything, should the EU do with this competence? As noted earlier, ${ }^{37}$ the focus in the development of EU private international law has, thus far, been squarely on 'internal' questions - principally (as explored further below ${ }^{38}$ ) on improving the efficient functioning of the internal market, and more recently on establishing an area of freedom, security and justice. ${ }^{39}$ The remainder of this article examines the possible ways in which the EU might use private international law 'internationally'. What could or should the EU achieve (or try to achieve) with private international law in its external relations? To put this another way, what are the options for an EU private international law foreign policy?

\footnotetext{
33 Regulation (EC) No 593/2008 of the European Parliament and of the Council of 17 June 2008 on the law applicable to contractual obligations (henceforth, Rome I Regulation).

34 Regulation (EC) No 864/2007 of the European Parliament and of the Council of 11 July 2007 on the law applicable to non-contractual obligations (henceforth, Rome II Regulation).

35 Rome I Regulation, Article 2; Rome II Regulation, Article 3.

36 Regulation (EC) No 662/2009 of the European Parliament and of the Council of 13 July 2009 establishing a procedure for the negotiation and conclusion of agreements between Member States and third countries on particular matters concerning the law applicable to contractual and non-contractual obligations.

${ }^{37}$ See supra $\mathrm{n} 1$.

${ }^{38}$ See infra section IV.A.

39 See, for example, the Recast Brussels I Regulation 2012, Recital 3 (discussing 'the objective of maintaining and developing an area of freedom, security and justice' and 'the proper functioning of the internal market') and Recital 4 (discussing 'the sound operation of the internal market').
} 
This chapter identifies two general approaches which might be pursued through 'outward facing' private international law, each of which encompasses two distinct techniques. The first approach may be described as 'think local act global' - this refers to the possibility that the EU might take international steps, using its external competence, in order to achieve (primarily) domestic policy goals. Under this approach, we can distinguish between (i) multilateral and (ii) bilateral or regional action. The second approach may be described as 'think global act local' - this refers to the possibility that the EU might take domestic steps, using its internal competence, in order to achieve (primarily) international policy goals. Under this approach, we can distinguish between techniques which focus on (i) private international law rules and (ii) private international law exceptions. Each of these two approaches (and four techniques) is discussed in turn, examining the different goals which might be identified, the action which has been or could be taken by the EU, and the challenges which are presented.

\section{III. 'Think local act global'}

As noted above, this approach considers what steps the EU might take externally or internationally to achieve (primarily) domestic policy goals - what the EU might achieve locally by acting globally (using its exclusive external competence) in the field of private international law. It distinguishes between the pursuit of private international law objectives through multilateral treaties, and the pursuit of those objectives through bilateral or regional treaties.

\section{A. Pursue private international law objectives through multilateral treaties}

Perhaps the most obvious thing which the EU might do externally in relation to private international law is to participate in efforts to reach international harmonisation or consensus. The achievement of such objectives has long been an aspiration for private international law, as it has long been recognised that many of the policy goals for private international law can only be met through an internationalised approach. Indeed, historically private international law developed as part of an internationalised 'law of nations', and it was only in the nineteenth century that independent national law traditions of private international law developed - the international harmonisation of private international law seeks (in a rough sense) to reverse this historical process. ${ }^{40}$

\section{Goals}

The reasons why the global harmonisation of private international law has been pursued are well understood. If states limit the jurisdictional overlap of their courts, apply the same choice of law rules, and recognise each other's judgments, this increases 'decisional

\footnotetext{
40 See further, eg, Alex Mills, 'Rediscovering the Public Dimension of Private International Law' [2011] Hague Yearbook of International Law; (2012) 30 The Netherlands Journal of Private International Law, Nederland Internationaal Privaatrecht (NIPR) 371; Alex Mills, 'The Private History of International Law' (2006) 55 International and Comparative Law Quarterly 1.
} 
harmony' - consistency in civil dispute resolution, and thereby the avoidance of regulatory conflict. This should also reduce the incentives for forum shopping, which in conjunction should lead to the more efficient resolution of disputes and thereby improve the functioning of global markets. ${ }^{41}$ Indeed, as discussed further below, these are all objectives which lie behind the pursuit of harmonisation of private international law in the European Union - increasing decisional harmony in the EU, leading to improvements in the efficiency of the internal market. The pursuit of equivalent objectives internationally might be viewed as a natural extension of this approach.

This technique could also be used to pursue other less traditional policy objectives, which are arguably having an increasing influence in private international law. Harmonisation of jurisdictional rules might address not only concerns of jurisdictional overlap (creating a risk of conflict), but also concerns of jurisdictional gaps (creating a problem of access to justice). Differences in national jurisdictional approaches may increase the risk that parties are left without any available forum, and thus that claimants are left without a remedy. ${ }^{42}$ Such concerns were reflected in the European Commission's initial proposal for the Recast Regulation, ${ }^{43}$ to extend the Regulation to non-EU domiciled defendants, which incorporated a 'forum of necessity' rule with the underlying idea that this would address concerns of access to justice, thus viewing and incorporating those concerns as a private international law objective. ${ }^{44}$ As discussed further below, this is an objective which may also be pursued unilaterally - and indeed the European Commission's proposal in relation to the Recast Regulation would have been such a unilateral measure (in the sense that the EU would have been acting unilaterally rather than in cooperation with non-Member States). The pursuit of this objective carries a greater risk of creating regulatory conflict if it is unilateral, however, and thus it may be better pursued through multilateral harmonisation efforts.

The description of the technique of multilateral harmonisation as an example of a 'think local act global' approach presumes that the purpose behind this approach would be to achieve domestic policy goals for the EU. This technique could, however, also be pursued for more altruistic reasons (setting firmly aside the question of whether altruism is reducible to a different form of local interest ${ }^{45}$ ) - increased efficiency of global markets could also, for example, be motivated by a desire to help alleviate poverty in developing states. It is, however, probably not too cynical to suggest that the primary motivation for the EU in pursuing multilateral harmonisation of private international law is likely to be the potential for economic benefits to the EU itself from increased efficiency in global cross-border activity.

\footnotetext{
41 See further eg Alex Mills, 'The Identities of Private International Law - Lessons from the US and EU Revolutions' (2013) 23 Duke Journal of Comparative and International Law 445.

${ }^{42}$ See further eg Alex Mills, 'Rethinking Jurisdiction in International Law' (2014) 84 British Yearbook of International Law 187 at p.221ff.

43 Proposal for a Regulation of the European Parliament and of the Council on jurisdiction and the recognition and enforcement of judgments in civil and commercial matters (Recast), COM(2010) 748 final, 2010/0383 (COD), http://ec.europa.eu/justice/policies/civil/docs/com 2010748 en.pdf.

44 Article 26. Note also the Lugano Opinion (supra n 5), in the which the Court noted (at [141]) that 'The smallest lacuna in those rules could give rise to the concurrent jurisdiction of several courts to resolve the same dispute, but also to a complete lack of judicial protection, since no court may have jurisdiction to decide such a dispute.'

45 See, notoriously, Ayn Rand, 'The Virtue of Selfishness' (Signet, 1964).
} 


\section{Action}

The principal form of action which could be undertaken by the EU to achieve these objectives would be participation in multinational initiatives relating to private international law. Although there are a range of international organisations whose work may encompass questions of private international law (including UNIDROIT ${ }^{46}$ and UNCITRAL ${ }^{47}$ ), the primary forum in which such initiatives are negotiated is the Hague Conference on Private International Law. ${ }^{48}$ The Hague Conference is an international organisation which grew out of a series of international conferences held in the late nineteenth and early twentieth centuries, seeking to promote international harmonisation of private international law. ${ }^{49}$ It has welcomed and facilitated the involvement of the EU by opening its membership to 'Regional Economic Integration Organisations', ${ }^{50}$ and the EU duly became a Member on 3 April 2007 (to date, the only REIO to join the Hague Conference). ${ }^{51}$

The direct participation of the EU in the Hague Conference has had a narrow but not insignificant practical output thus far. In 2014 the EU became a party to the Convention of 23 November 2007 on the International Recovery of Child Support and Other Forms of Family Maintenance, and the Protocol of 23 November 2007 on the Law Applicable to Maintenance Obligations. ${ }^{52}$ The most prominent involvement of the EU in the work of the Hague Conference thus far has, however, been in relation to the Convention of 30 June 2005 on Choice of Court Agreements. The EU signed the Convention in 2009,53 and in late 2014 the decision was made to ratify the Convention, ${ }^{54}$ which became effective on 1 October 2015 (on the first day of the month following the expiration of three months after the deposit). This Convention governs the effectiveness of (nonconsumer) jurisdiction agreements in favour of the courts of any Contracting State to the Convention, unless the parties to the jurisdiction agreement are resident (as defined in Article 4(2)) in EU Member States or in non-Contracting States. ${ }^{55}$ It thus displaces either the Brussels I Regulation (if the choice is in favour of a Member State court) or the

\footnotetext{
46 See generally http://www.unidroit.org/.

${ }^{47}$ See generally http://www.uncitral.org/.

48 See generally www.hcch.net. The European Commission's 'Action Plan Implementing the Stockholm Programme: Delivering an area of freedom, security and justice for Europe's citizens' (COM/2010/0171 final, 20.4.2010) includes a commitment to 'Continue to support the Hague Conference on Private International Law and encourage its partners to ratify the conventions where the EU is or will become a Party or where all Member States are Parties.' ${ }^{49}$ See generally Alex Mills and Geert De Baere, 'T.M.C. Asser and Public and Private International Law: The life and legacy of "a practical legal statesman" (2011) 42 Netherlands Yearbook of International Law 3; J.H.A. van Loon, "The Hague conference on private international law: an introduction', in P.J. van Krieken, and D. McKay, eds, The Hague: Legal Capital of the World (The Hague, TMC Asser Press, 2005); Kurt Lipstein, 'One Hundred Years of Hague Conferences on Private International Law' (1993) 42 International and Comparative Law Quarterly 553.

${ }^{50}$ http://www.hcch.net/index en.php?act=conventions.text\&cid=29\#reio.

51 http://www.hcch.net/index en.php?act=states.details\&sid=220. See generally Hans van Loon and Andrea Schulz, 'The European Community and the Hague Conference on Private International Law', in Bernd Martenczuk and Servaas van Thiel (eds), Justice, Liberty, Security: New Challenges for EU External Relations (Brussels University Press, 2008).

$52 \mathrm{http}: / /$ www.hcch.net/index en.php?act=states.details\&sid=220.

${ }^{53}$ Council decision No 2009/397/EC of 26 February 2009.

5410 December 2014, Council Decision 2014/887/EU.

55 Article 26(6).
} 
residual national rules on jurisdiction (if the choice is in favour of a non-Member State court and the defendant is not domiciled in a Member State). ${ }^{56}$ It therefore represents an initial foray into the adoption of externally-oriented EU jurisdictional rules based on what is intended to be a multilateral model, with the aim to benefit both EU parties (who may achieve greater certainty in relation to jurisdiction agreements in favour of non-EU courts) as well as non-EU parties (who may achieve greater certainty in relation to jurisdiction agreements in favour of EU or non-EU courts).

There is a broad scope of other potential activity which could be carried out by the EU through participating in multilateral harmonisation initiatives. Another important example is the continued work on the 'Judgments Project' at the Hague Conference. ${ }^{57}$ This long-running project aims to achieve an internationalised agreement which is functionally equivalent to the Brussels I Regulation, providing for harmonised rules of jurisdiction in civil and commercial matters, in order to facilitate the recognition and enforcement of judgments between states. The Hague Choice of Court Convention was essentially a narrower 'spin-off of the work on this project, but work on the broader project has been resumed, with the European Union as a participant Member in the Working Group. ${ }^{58}$ This project faces significant challenges in striving to harmonise widely different traditions of national (and potentially regional, in the case of the EU) jurisdictional rules, but the payoffs of success would also be very significant.

If successful, the Judgments Project would be likely to lead to the adoption of EU rules governing jurisdiction in the courts of Member States over non-Member State parties (now principally but not exclusively ${ }^{59}$ regulated by national law), to reflect the terms of an international convention. As noted above, the adoption of such rules was already proposed by the European Commission as a unilateral step in its initial proposal for a Recast Brussels I Regulation, but there would clearly be greater benefit in pursuing this through a coordinated international process of harmonisation. As already discussed, there are a range of potential international and EU benefits in coordinating jurisdiction between Member States and non-Member States, including traditional goals of reducing overlapping regulation, and non-traditional goals such as the avoidance of jurisdictional gaps to ensure access to justice for claimants. In addition, harmonisation of jurisdictional rules over non-Member State defendants would also increase the equal application of the current rules under the Brussels I Regulation. This is because (as also set out above) the scope of the lis pendens rules binding on Member States is partially dependent on the rules

\footnotetext{
${ }^{56}$ If the defendant is domiciled in a Member State, and the choice is in favour of a non-Member State court, then this raises the 'reflexive effect' problem under the Regulation - see infra $\mathrm{n} 102$ and accompanying text. If none of the parties is resident in a Contracting State, it is also possible that the Convention is displaced by another treaty - see Article 26(2).

57 See generally http://www.hcch.net/index en.php?act=text.display\&tid=149. Note also the European Parliament resolution of 23 November 2010 on civil law, commercial law, family law and private international law aspects of the Action Plan Implementing the Stockholm Programme (2010/2080(INI), at [35] (urging the Commission 'to use its best endeavours at the Hague Conference to revive the project for an international judgments convention').

58 See eg Report of the Fourth Meeting of the Working Group on the Judgments Project, 3-6 February 2015, available at http://www.hcch.net/upload/wop/gap2015pd07b en.pdf.

${ }^{59}$ Such cases are, for example, affected by Articles 24 and 25 of the Recast Brussels I Regulation 2012 - see supra n 19.
} 
of jurisdiction over non-Member State defendants, which is presently a matter of national law that varies between Member States.

The successful negotiation of an international convention pursuant to the Judgments Project would also be likely to lead to amendments to the Brussels I Regulation to cover recognition and enforcement of non-Member State judgments, an issue also presently governed by national law (in this case, one which the European Commission did not propose to change in the Recast Regulation). It has already been noted above that this situation creates potential issues regarding the application of the new Brussels I Regulation lis pendens rules for third state proceedings, which depend on the question of whether those proceedings are likely to give rise to a judgment which is enforceable in the courts of the Member State second seised of a dispute. If this issue were governed by harmonised rules pursuant to an international convention, the scope of the third state lis pendens obligations under the Brussels I Regulation would also effectively be harmonised. There would evidently be further international benefits for EU private parties in enabling them to have judgments enforced more readily in non-Member States, and perhaps even more valuably in enabling them to anticipate more clearly when such enforceability is likely to arise (and thus when litigation is worth pursuing).

The Hague Conference on Private International Law could also offer further opportunities to participate in multilateral harmonisation efforts in the field of choice of law. The Hague Conference has, for example, recently adopted 'Principles on Choice of Law in International Commercial Contracts' (approved on 19 March 2015). ${ }^{60}$ While these are not a formal international convention, it is possible that they may prove influential as a matter of soft law harmonisation. The European Union was not represented in the Working Group which prepared these principles (the members were largely academic experts participating in their individual capacity rather than as representatives of states). However, the Rome I Regulation was evidently a strong influence on those participating, many members of the Working Group were from EU Member States, ${ }^{61}$ and the principles were formally approved by the Members of the Hague Conference including the European Union. As discussed above, successful harmonisation efforts in the field of choice of law (whether through formal or more informal soft law techniques) are likely to decrease incentives for forum shopping and reduce the risk of conflicting judgments arising in different states. There are thus clear benefits to the EU in participating in or supporting such initiatives, even if these may require amendments to EU choice of law rules to bring them more closely in line with any international consensus which is reached.

\section{Challenges}

Multilateral harmonisation of private international law has been actively pursued for more than a century, since the first Hague Conferences in the 1890 s, with limited success. ${ }^{62}$ If the EU pursues such negotiations, it should not expect quick results - although that is by

\footnotetext{
${ }^{60} \mathrm{http}: / /$ www.hcch.net/index en.php?act=conventions.text\&cid=135.

${ }^{61}$ For a list see eg http://www.hcch.net/upload/wop/gap2014pd06rev en.pdf.

62 See Mills and De Baere (2011), supra n 49.
} 
no means to suggest that the game is not worth the candle. Perhaps the single greatest difficulty of such initiatives is that they depend on other states being similarly motivated to pursue harmonisation, which requires agreement that the goals this would pursue are valuable and politically achievable both domestically and internationally.

Reaching agreement on international rules of private international law is also likely to come at a cost in terms of the content of the rules themselves. It is unlikely that the EU would be able to persuade the international community simply to adopt whatever rules would be judged by the EU to be best suited to the task. Significant compromise may be required for the sake of agreement. This means that the pursuit of international harmonisation may lead to private international law rules which are 'worse' than the rules which the EU would wish to have adopted, and which the EU would adopt were it simply to act unilaterally. That may be a price worth paying for the benefits of internationalisation, but there is a cost/benefit analysis which would have to be undertaken in making that determination.

In the context of rules of jurisdiction (over non-Member State defendants) or the recognition and enforcement (of non-Member State judgments), these issues are perhaps less of a concern because such matters are presently governed almost exclusively by national law, so there is no existing set of 'EU ideal rules' which would need to be compromised - although that might well be generated in the course of negotiations. One particular and instructive context in which the jurisdictional rules of the European Union have ventured into matters relating to non-Member State jurisdiction is in the new lis pendens rules of the Recast Brussels I Regulation. As noted above, those rules permit the courts of a Member State to decline jurisdiction where a non-Member State court has been first seised of the same (or a related) dispute. These rules are aimed at achieving a reduction in parallel proceedings and thus the risk of conflicting judgments arising between Member State and non-Member State courts. They thus recognise and pursue internationalised goals - they are not concerned with the efficient functioning of the internal market, but with questions of EU external relations.

These rules have, however, not been adopted as a result of any international negotiation or consensus, but as a purely unilateral measure. They offer no guarantee that the courts of non-Member States will apply equivalent rules if they are second seised of a dispute where the courts of a Member State are first seised. This means that the EU, in adopting these rules, has unilaterally given up jurisdiction in a range of cases, essentially for the benefit of ensuring the effectiveness of non-Member State court judgments (and thereby the claimants in those proceedings). The rules go a small way toward achieving an international objective of private international law - reduction in the risk of parallel proceedings and conflicting judgments - but in doing so unilaterally, they come with a significant additional cost. Giving the courts of EU Member States the power to stay proceedings in favour of non-Member State courts, where the Member State court is second seised, has the consequence that fewer cases will be decided in EU courts, and thus regulated by at least EU choice of law rules as well as potentially by EU or Member State mandatory rules. Acting unilaterally in this way is therefore a form of jurisdictional abstention which achieves limited benefits at potentially significant costs. 
Important challenges are still likely to arise even where international harmonisation is pursued in a multilateral way. The issues are perhaps most significant and evident in the context of the Rome I and II Regulations on choice of law in contractual and noncontractual obligations (respectively). These regulations are principally focused on achieving decisional harmony between Member State courts - they aim to ensure that each court will apply the same governing law to civil disputes, thereby reducing incentives for forum shopping. ${ }^{63}$ However, there is something of a mismatch between the scope of the rules and their objectives. The rules in these regulations are universal in application they govern the relevant choice of law question regardless of what connections the dispute has with the internal market or non-Member States. This means that in many cases they will be regulating the law governing disputes where there is no possibility of forum shopping between different Member States, because only one Member State would have a basis of jurisdiction, but there is a significant risk of forum shopping between a Member State court and a non-Member State court. Addressing that concern would require harmonisation of the rules with non-Member States - the Rome I and II Regulations do not, of course, govern choice of law in non-Member State courts (although they might serve as an influential soft law model for some other states when it comes to developing their own choice of law rules).

Achieving international harmonisation of choice of law rules would, however, be very likely to necessitate changes in the Rome I and II Regulations to reflect the terms of an international agreement. This would require one of two compromises. First, the universality of these rules might be preserved, but their application between Member States would have to change, thus leading to the adoption of rules which are less tailored to the objectives of the internal market. Or second, the universality of the rules might have to be compromised, so that a distinction is drawn between internal market cases and those where the risk of conflicting decisions arises in relation to a non-Member State. This would allow the current rules to continue to apply to internal market situations, but an international consensus to be applied to other cases. Which approach is preferable is difficult to determine in the abstract - this will depend on whether the substantive compromises in the first outweigh its benefits of relative simplicity. For the latter approach, difficulties would arise particularly in relation to disputes which have connections with more than one Member State as well as a non-Member State - the experience of the Brussels I Regulation suggests that the boundary between international and internal market cases is likely to raise significant practical difficulties, ${ }^{64}$ although EU practice suggests a tendency to rely on disconnection clauses in comparable contexts. ${ }^{65}$ Arguments could be made in favour of either approach, but each would involve accepting a degree of compromise for the sake of achieving international objectives.

To put these considerations in general terms, thus far the development of EU private international law rules has focused on internal market objectives. If internationally harmonised rules were negotiated, this would almost certainly not involve the

\footnotetext{
${ }^{63}$ See infra section IV.A.

${ }^{64}$ See infra text accompanying n 102.

${ }^{65}$ See eg Marise Cremona, 'Disconnection Clauses in EU Law and Practice', in C. Hillion and P. Koutrakis (eds), Mixed Agreements Revisited: The EU and its Member States in the World (Hart, 2010).
} 
international adoption of these EU rules, because they have been developed with this particular context and focus in mind, and because some important actors - notably the United States - take quite different approaches to these issues than the EU. Adopting harmonised rules would thus mean choosing one of two options. First, accepting that different rules should apply in these different (internal and international) contexts - the adoption of a form of 'variable geometry' in private international law. ${ }^{66}$ This comes with the cost that there are difficult boundary problems to resolve, particularly in relation to disputes which are both internal market and international questions. Second, adopting the internationally agreed standards for internal market questions as well, thus ensuring uniformity, but at the cost of agreeing to rules which are less tailored to the needs of the internal market. It is not essential that a single approach be adopted across private international law - an argument might be made, for example, that the first approach should be adopted in the context of jurisdiction and the recognition and enforcement of judgments, and the second in the context of choice of law. But it should be understood that whichever option is taken comes with both benefits and costs. If multilateral private international law rules are to be negotiated and agreed, difficult decisions must be made concerning whether (and if so how) these rules supplement or supplant those developed in the EU thus far.

\section{B. Pursue private international law objectives through bilateral or regional treaties}

If a multilateral approach to the international harmonisation of private international law could be achieved, then clearly that would have the greatest benefit, leading to increased efficiency in dispute resolution across the globe. A truly global approach to harmonisation is, however, also the most difficult to undertake. The pursuit of bilateral or regional efforts at harmonisation might be considered as a more modest but also more feasible alternative.

\section{Goals}

The potential pursuit of bilateral or regional harmonisation of private international law rules might be viewed as analogous to developments in the negotiation of international trade agreements. Clearly the greatest benefits would be achieved through multilateral negotiations, and indeed enormous efforts have been put into striving to achieve an international consensus on trade issues, most recently through the Doha round of trade talks. ${ }^{67}$ The Doha round has, however, thus far proved unable to reach a global agreement. As a result, many states have fallen back to bilateral or regional trade negotiations, to try to achieve more modest but obtainable benefits, such as the Comprehensive Economic and Trade Agreement (CETA) between the EU and Canada, ${ }^{68}$ and the Transatlantic Trade and Investment Partnership (T'TIP) agreement currently

\footnotetext{
66 Alex Mills, 'Variable Geometry, Peer Governance, and the Public International Perspective on Private International Law', in D. Fernandez Arroyo and H. Muir Watt (eds), Private International Law and Global Governance (Oxford University Press, 2014).

${ }^{67}$ See generally https://www.wto.org/english/tratop e/dda e/dda e.htm.

68 See further eg http://ec.europa.eu/trade/policy/in-focus/ceta/.
} 
being negotiated by the EU and United States. ${ }^{69}$ These (potential) agreements could be viewed in two ways. They might be viewed as an alternative means of bargaining or negotiating towards a multilateral consensus, by setting down clear terms which it is hoped will prove a model for other agreements, either informally or through the effect of 'most favoured nation' clauses. ${ }^{70}$ They might also, however, be viewed as an end in themselves. If a multilateral agreement is not possible, then limited but significant benefits may be achieved through bilateral or regional agreements with key trading partners. A further and similar comparison might be made with international investment law. The failure of efforts to establish multilateral consensus (such as the MAI negotiations in the 1990s) led to the adoption of a wide range of bilateral investment treaties by a range of states, including Member States of the EU. ${ }^{71}$ The fact that (since the Treaty of Lisbon) the EU now has exclusive external competence in the field means that the $\mathrm{EU}$ is at least contemplating negotiating its own bilateral investment treaties, ${ }^{72}$ including as part of CETA and T'TIP, and has set up internal arrangements to manage the potentially complex issues of responsibility for their violation. ${ }^{73}$

The arguments would be very closely analogous in the context of private international law. If a multilateral consensus cannot be achieved on the harmonisation of private international law rules, then the best way to proceed (either as an interim step or alternative goal) may be to strive to achieve agreement on the harmonisation of private international law with key trading partners. The goals of such initiatives would be very similar to those of multilateral efforts, as discussed above - the idea would be that EU actors, and potentially others, would benefit from increased harmony and efficiency in relations between the states who become parties to the agreement. An agreement between the EU and the US, for example, might harmonise choice of law rules, meaning that parties involved in commercial activities between the EU and the US could be certain of what law governs their legal relations, regardless of where the case might be litigated. Increased certainty on such matters would, at least in theory, increase transAtlantic business activity, leading to increased efficiency in the functioning of both economies. Similar benefits could be achieved through harmonisation of jurisdictional rules, enabling parties to predict more clearly where they might be sued and reducing the possibility of overlapping exercises of jurisdiction, as well as through the rules governing the recognition and enforcement of judgments.

\footnotetext{
${ }^{69}$ See further eg http://ec.europa.eu/trade/policy/in-focus/ttip/.

${ }^{70}$ See generally https://www.wto.org/english/thewto e/whatis e/tif e/fact2 e.htm.

${ }^{71}$ See generally Alex Mills, 'Antinomies of Public and Private at the Foundations of International Investment Law and Arbitration' (2011) 14 Journal of International Economic Law 469; M. Sornarajah, 'The International Law on Foreign Investment' (Cambridge: Cambridge University Press, $3^{\text {rd }}$ edn, 2010).

${ }^{72}$ See generally http://ec.europa.eu/trade/policy/accessing-markets/investment/; 'Special Issue: The Anatomy of the (Invisible) EU Model BIT' (2014) 15(3)-(4) Journal of World Investment and Trade; Angelos Dimopoulos, 'EU Foreign Investment Law' (Oxford University Press, 2011).

${ }^{73}$ Regulation (EU) No 912/2014 of the European Parliament and of the Council of 23 July 2014 establishing a framework for managing financial responsibility linked to investor-to-state dispute settlement tribunals established by international agreements to which the European Union is party, OJ L 257, 28.8.2014, p.121.
} 


\section{Action}

Since the conferences in the Hague in the late nineteenth century, there has been a strong tradition of aspiring to or pursuing a universal form of multilateralism in private international law, and for good reason - international harmonisation would clearly offer the greatest potential benefits. However, states have also historically often entered into bilateral or regional private international law agreements. The private international law rules adopted by the European Union may themselves of course be viewed as the most successful example of 'regional' private international law, but are perhaps a special case because of the EU's institutional context, and there are other well-known (and more unambiguously regional) examples in both Central and South America. ${ }^{74} \mathrm{~A}$ wide range of bilateral or regional private international law treaties also operated between states within the EU prior to the adoption of European Community or Union regulation, ${ }^{75}$ and some Member States continue to be bound by bilateral agreements with non-Member States which affect their national private international law rules. ${ }^{76}$ Such agreements need not take the form of formal treaty arrangements, but may also be established through reciprocal legislative schemes. In the United Kingdom, for example, the Administration of Justice Act 1920 was adopted as a means for Commonwealth states to enter into reciprocal arrangements for the enforcement of judgments. It was supplemented and partially replaced by a similar scheme in the Foreign Judgments (Reciprocal Enforcement) Act 1933, which was open to non-Commonwealth states (although is also applicable to some Commonwealth states such as Australia), and in practice in fact extended to a number of Western European states (including France, Germany, Italy, Belgium and the Netherlands) prior to the adoption of European rules.

The particular question here is whether the EU might extend its 'negotiation' of private international law rules beyond its own borders, to encompass agreement with other states. There is of course one well known example of exactly this - the Lugano Convention. ${ }^{77}$ This Convention was negotiated as a complement to the Brussels Convention of 1968, as a means of extending the terms of that convention to states who are not Member States of the European Union but are part of the European Free Trade Area, and who therefore wish to participate in the internal market. This is again perhaps a special case rather than a generalisable model, and aside from this development the EU has not (yet) attempted to negotiate bilateral or regional international agreements on

\footnotetext{
${ }^{74}$ For example, the Inter-American Convention on the Law Applicable to International Contracts (Mexico Convention) (1994); the Buenos Aires Protocol on International Jurisdiction in Disputes Relating to Contracts (1994); and the Los Leñas Protocol on the Recognition and Enforcement of Judgments of other Mercosur States (1992).

75 See P Jenard, 'Report on the Convention on jurisdiction and the enforcement of judgments in civil and commercial matters signed at Brussels, 27 September 1968', OJ C 59/1, 5 March 1979, at pp.6-7; Brussels Convention on jurisdiction and the enforcement of judgments in civil and commercial matters (1968), Consolidated version OJ C 27/1, 26 January 1998, Article 55.

76 See further discussion in 'Study: Possibility and terms for applying Brussels I Regulation (recast) to extra-EU disputes', Directorate General for Internal Policies, Policy Department C: Citizens' Rights and Constitutional Affairs, at the request of the European Parliament Committee on Legal Affairs, PE 493.024 (March 2014), at p.42 (available at http://www.europarl.europa.eu/RegData/etudes/etudes/join/2014/493024/IPOLJURI ET\%282014\%29493024 EN.pdf).

77 Lugano Convention of 16 September 1988 on jurisdiction and the enforcement of judgments in civil and commercial matters, OJ 1988 L 391/9.
} 
private international law harmonisation. There is, as noted above, a strong argument that such measures should only be adopted as a fall-back if multilateral efforts prove unsuccessful, and perhaps it would be premature for the EU as a relatively new player in international harmonisation discussions to reach any such conclusion. However the possibility should not be ignored that, as in the context of trade law or investment law, bilateral or regional agreements with key trading partners may at some point be viewed as a preferable alternative to the very difficult task of reaching a global consensus in matters of private international law. ${ }^{78}$

\section{Challenges}

A key drawback of pursuing bilateral or regional agreements on private international law harmonisation would evidently be that such agreements could only achieve limited benefits compared with multilateral action. EU commercial actors would, for example, only have increased certainty in respect of their commercial relations with the other states who are parties to such agreements. There is also a significant risk associated with such efforts, which is that the agreements negotiated with different bilateral or regional partners might unavoidably be on different terms. This would have the consequence that private international law would become harmonised in terms of relations between particular states, but more fragmented in terms of the rules applicable within a given state. For example, one might imagine a situation in which the EU and US agreed to apply the same choice of law rules where a company from one partner did business in the other, and the EU and China reached an equivalent agreement but on different terms. EU companies would have the benefit of a harmonised approach for each of these systems individually - they would know what law would govern their business activities in the United States regardless of whether the dispute was litigated in the US or in the EU, and the same would apply in relation to China. However, they would have to know and understand two different sets of private international law rules if they were doing business in both states, and no doubt face difficult boundary issues concerning the scope of application of each system. The risk here is not only that this would frustrate rather than enhance the achievement of multilateral goals, but also that it might well make matters significantly worse for private parties.

On the other hand, bilateral or regional agreements could perhaps be pursued with a very limited 'fixed' model - attempting to reach a more local or limited consensus. Where multinational negotiations may require significant compromise to achieve agreed rules, negotiating only with more like-minded partners, such as those from similar legal traditions, might achieve an agreement which is closer to each party's ideal position. ${ }^{79}$ (Identifying parties with 'similar legal traditions' is, of course, somewhat complicated in the case of the EU, which has its own sui generis legal culture built on the foundations of diverse national traditions.) Agreeing on harmonised rules of private international law with a more limited group of states may thus require less compromise than efforts to

\footnotetext{
${ }^{78}$ See further discussion in 'Study: Possibility and terms for applying Brussels I Regulation (recast) to extra-EU disputes' (2014), supra n 76.

${ }^{79}$ The EU may of course also be able to effectively mandate a relatively fixed model law in negotiations with weaker parties.
} 
achieve international agreement, leading to more satisfactory rules. It might even be possible to adopt a standard form agreement which is then adopted in multiple (regional or bilateral) contexts, thereby minimising the risks of fragmentation discussed above.

\section{IV. 'Think global act local'}

The second major approach which could be adopted by the EU in the field of private international law is quite distinct. It considers what internal steps the EU might take which are designed to have external policy effects - what the EU might do globally, through acting locally. Because this approach involves acting locally, it does not necessarily require the use of any external competence in the field of private international law. It is, however, more broadly concerned with the ways in which the EU might use private international law in its external relations - action which the EU might take domestically with private international law with a view to pursuing substantive regulatory goals through projecting EU values and policies internationally. This section distinguishes between the use of private international law rules and exceptions to achieve these goals, dealing with each in turn.

\section{A. Pursue regulatory objectives through private international law rules}

Under the first general approach outlined above - the international, regional or bilateral harmonisation of private international law rules - the focus naturally tends to be on uniformity rather than content. The emphasis is on ensuring that private international law rules are the same in different states, rather than identifying what the rules actually should be. An alternative approach for the EU would be to focus on the formulation of EU private international law rules to achieve particular policy goals. Of course this has already been the case 'internally' - the EU has sought to adopt private international law rules which achieve certain policy objectives as part of the internal market. The EU's lawmaking processes require approval by representatives of the Member States, and so compromises may be (and have been) made in the content of the private international law rules adopted to ensure that agreement is reached, but where a rule is adopted it automatically applies equally throughout the EU, and thus there is more scope to focus on identifying what rules will best serve the EU's own policies. The possibility considered here is that such an approach could or should be extended, independently of the question of harmonisation, so that EU private international law rules are adopted in order to serve external (as well as potentially internal) policy objectives, using private international law as a means to 'project' EU values or interests outside the European Union.

\section{Goals}

Understanding this approach requires some further background discussion of the functions and effects of rules of private international law. At great risk of overgeneralisation, the main focus in the development of private international law in the national traditions of European Member States has been on 'appropriateness' - ensuring that an appropriate court hears a case, and that an appropriate law is applied. This rather broad concept of appropriateness encompasses both 'private' and 'public' considerations 
- questions of fairness to private parties (do the rules meet their reasonable expectations?), as well as principles of public international law jurisdiction (which state or states have the power to regulate this particular dispute?). ${ }^{80}$ If private parties are forced to litigate in inconvenient or unexpected courts, or governed by inappropriate systems of law, this is hardly consonant with resolving their disputes fairly. At the same time, the rules function within the context of a public international law system which governs the coexistence of sovereigns with their own regulatory interests. Under public international rules of jurisdiction, states can generally only regulate people and events in their territory, as well as the extra-territorial conduct of their nationals and (arguably) residents, ${ }^{81}$ including in relation to civil matters.

The 'appropriate' allocation of regulatory authority in this (complex) way is a distinct policy goal which private international law has long pursued. (An alternative way of justifying this is as a horizontal dimension of the principle of subsidiarity - ensuring that legal decisions are made as closely as possible to those principally affected by them..$^{82}$ EU rules of private international law are no different in this regard. In the development of EU rules of private international law the focus has generally been on what kind of distribution would meet the needs of the European internal market - how authority should be distributed between Member States. Rules of EU private international law could, however, also be developed with an international focus on how regulatory authority should best be allocated when a dispute arises with connections to both nonEU Member States and EU Member States, as explored further below.

In modern private international law, particularly but by no means exclusively in the United States, ${ }^{83}$ it has also been increasingly accepted that private international law rules may be attuned to achieve other regulatory goals. Jurisdictional or choice of law rules may focus not on appropriateness, but (for example) on ensuring access to justice for claimants, or ensuring that weaker parties gain the protection of their home courts or laws. Again these are matters which the EU has largely pursued internally, as part of the existing range of private international law rules focused on the interests of the internal market, but as explored further below they could also be pursued externally. To put these issues most generally, it is private international law rules which determine whether the courts of a European Member State have jurisdiction in civil matters, and if so, whether they will apply the law of a Member State (which incorporates any applicable EU law). Private international law rules thereby determine the scope of application of Member State and EU law in civil matters - and thus may be used to limit that scope in keeping with traditional private international law principles and goals, or to project the application of Member State private law to a range of extraterritorial contexts for a range of purposes.

\footnotetext{
${ }^{80}$ See generally Alex Mills, 'The Confluence of Public and Private International Law' (Cambridge University Press, 2009).

${ }^{81}$ See further Mills (2014), supra $\mathrm{n} 42$.

82 See further Alex Mills, 'Federalism in the European Union and the United States: Subsidiarity, Private Law and the Conflict of Laws' (2010) 32 University of Pennsylvania Journal of International Law 369, at p.406ff.

${ }^{83}$ See generally Mills (2013), supra n 41.
} 
The pursuit of these goals would in many contexts benefit from international harmonisation, but would not necessarily require it. In practice, the two approaches pursuing international harmonisation or pursuing substantive policy goals - are likely to be in tension with one another. As discussed above, international harmonisation of private international law rules is likely to require a degree of compromise concerning the content of those rules, which means accepting that the rules are not attuned to achieve the policy objectives which the EU would ideally like them to serve. The benefits of harmonisation, such as an increase in decisional harmony, are likely to come at a cost in terms of the content of the rules and the policies they pursue. Evaluating these different policy considerations against each other is a difficult task, but one which the EU ought to undertake as it considers exercising external competence in private international law.

\section{Action}

As noted above, the Rome I and II Regulations, dealing with choice of law in contractual and non-contractual obligations (respectively), already apply in relation to non-internal market situations. They determine which law governs a dispute heard in the courts of a Member State, regardless of whether the disputed events or disputing parties are partially or wholly inside or outside the internal market. As also already noted above, however, there is something of a mismatch between the scope of the rules and their objectives. The Rome I Regulation, for example, begins with a range of recitals including the following:

(1) The Community has set itself the objective of maintaining and developing an area of freedom, security and justice. For the progressive establishment of such an area, the Community is to adopt measures relating to judicial cooperation in civil matters with a cross-border impact to the extent necessary for the proper functioning of the internal market.

$\cdots$

(6) The proper functioning of the internal market creates a need, in order to improve the predictability of the outcome of litigation, certainty as to the law applicable and the free movement of judgments, for the conflict-of-law rules in the Member States to designate the same national law irrespective of the country of the court in which an action is brought. 84

These recitals reveal that the Regulation is focused on achieving objectives for the benefit of the internal market - leading to a focus on certainty and predictability for the parties, as well as decisional harmony between the courts of Member States (but perhaps with regrettably - relatively little focus on what the appropriate allocation of authority should $\left.b^{85}\right)$. There are, however, no recitals which explain what the Regulation is supposed to achieve in relation to non-internal market questions. For example, if proceedings are commenced in English courts arising out of a contract between an English and New York company, where the territorial connections of the contract are entirely in England and New York, there is no internal market issue, and the rules cannot achieve decisional

\footnotetext{
${ }^{84}$ Rome I Regulation, Recitals 1 and 6.

${ }^{85}$ See for example the criticisms in Mills (2013), supra n 41, at p.470.
} 
harmony because they do not bind the New York courts. The same applies, perhaps even more obviously, if parties from Hong Kong and Singapore enter into a contract and exclusively choose the English courts to resolve their dispute - the Rome I Regulation rules will again still apply to determine the law governing their contract, but they cannot aim to achieve decisional harmony or improve the efficient functioning of the internal market. As a result of its universal application, the curious effect of the Regulation is thus to project internationally a set of rules which have (apparently) been adopted to meet only (or at least primarily) the policy needs of the internal market. It appears that the approach adopted in the Rome I and II Regulations is to value uniformity of choice of law rules (applying the same choice of law rules for both internal market and international cases - which of course does have significant benefits), over having rules which actually serve an intended policy function for non-internal market cases. The EU's private international law foreign policy thus appears, in these areas, to be almost no policy at all, but rather the unilateral pursuit of domestic goals, with international consequences viewed as merely incidental.

What this section contemplates is that EU private international rules might instead be developed and designed with their international impact in mind. As noted above, this would of course come with disadvantages in terms of the additional complexity which it would create (potentially requiring more than one set of rules), but it would allow private international law rules to be designed to serve a range of other policy goals. Rules allocating regulatory authority between New York and England, for example, might be designed to meet different goals than those of the internal market, favouring appropriateness over certainty and predictability by incorporating more flexibility. If the choice to be made is between English and New York law, why should the internal market requirements of legal certainty (which justify a strong presumption in favour of the law of the characteristic performer's habitual residence under Article 4 of the Rome I Regulation) be relevant? Alternatively, rules governing the conduct of EU Member State companies in developing states might, for example, aim to ensure that those companies are governed by the substantive legal standards which are applicable in their home states, as a means of giving extraterritorial effect to those standards, to protect or constrain the company concerned. Whatever rules might be adopted, what is clear is that the current approach - applying a single set of rules designed for the internal market to all cases - is not the only approach, and in fact carries significant limitations in terms of what private international law may be used to achieve.

It is important to note that not all EU choice of law rules are primarily focused on certainty and predictability - other rules do have different policy objectives in mind, and the universal application of the rules also has the effect of projecting these policies internationally. For example, Article 7 of the Rome II Regulation provides as follows:

The law applicable to a non-contractual obligation arising out of environmental damage or damage sustained by persons or property as a result of such damage shall be the law determined pursuant to Article 4(1), unless the person seeking compensation for damage chooses to base his or her claim on the law of the country in which the event giving rise to the damage occurred. 
The evident effect of this rule, which gives the claimant the power to choose between the law of the place of the 'event giving rise to the damage' and the law of the place of the damage itself, is to maximise environmental protection by applying the law more favourable to the interests of the claimant (while allocating to the claimant the cost of determining which law that is). ${ }^{86}$ This rule applies not only if the choice is between the laws of two Member States, but also if it is between the law of one Member State and that of a non-Member State, or between the laws of two non-Member States. If, for example, an English company conducted mining operations in one developing state causing environmental damage in another developing state, those harmed could commence proceedings against the company in the English courts, ${ }^{87}$ and the choice of law rule would permit them to choose the more favourable of the two developing state laws. This is a clear example of an EU choice of law rule designed to achieve a substantive policy objective - increasing environmental protection - which has the effect of externally projecting this policy in relation to activities in non-Member States. It does so in a limited and perhaps crude fashion - only by allowing claimants a choice between the lex actus and lex damni, and not for example by imposing a minimum standard, such as by giving all claimants suing in a Member State the option of applying the law of that Member State (such option is only given where the action or environmental damage are in that Member State). Nevertheless, EU-based parties acting outside the EU need to take into account the possibility of environmental liability in both the place where they act and the place where their acts may cause damage. It is perhaps unclear whether this is by design or merely an incidental effect of the universal application of the Regulation, which applies all the choice of law rules 'externally', to international cases. As the rule was not in this case focused on the interests of the internal market, but on the more universal interests of the environment, its external projection is perhaps intentional and in any case arguably less problematic.

There are various other EU choice of law rules with similar effects. To give one example, Article 6 of the Rome I Regulation, which aims to protect consumers (by ensuring that they get the benefit of at least non-derogable protections under their home law), applies equally to both EU and non-EU parties. This means that this Article potentially protects non-EU consumers who are bringing proceedings against companies based in a Member State, who might well be sued in the courts of that Member State. The non-EU consumer may benefit by having the protection of their home law, even if the EU company itself took action only within the EU, and even if the non-Member State law offers greater consumer protection than that offered under EU law. This rule may have been designed with the protection of consumers in the internal market in mind, but again its effect (given the universal application of the Rome I Regulation) is to project its regulatory policy externally, potentially for the benefit of consumers living outside the EU (if their consumer protection rights are greater than those under EU law). Choice of law rules may thereby advance the EU policy of protecting consumers through disapplying EU law or standards - but perhaps inadvertently, may also harm consumer protection by failing

\footnotetext{
${ }^{86}$ See generally Michael Bogdan, 'The Treatment of Environmental Damage in Regulation Rome II', in John Ahern and William Binchy (eds), The Rome II Regulation on the Law Applicable to Non-Contractual Obligations (Brill, 2008).

87 Relying on Article 4 of the Recast Brussels I Regulation 2012. The English courts could not, at least absent exceptional circumstances, refuse to exercise jurisdiction, as discussed below.
} 
to enforce those standards for non-EU consumers by giving preference to the consumers' own law (if their consumer protection rights are weaker than those under EU law). Conversely, EU consumers purchasing products from non-EU companies, who may well be able to sue in their home courts, ${ }^{88}$ get the benefit of the consumer protection provisions under the law of their home state (including any protections under EU law). Non-EU companies doing business with consumers in the EU are thus held to regulatory standards adopted 'internally' by the EU - an external projection of those standards which in this case is more likely to be deliberate.

The discussion thus far has focused on choice of law rules because their current universal application clearly means that they apply in non-internal market contexts. Similar considerations would arise if the EU were to adopt jurisdictional rules for non-Member State defendants (as was initially proposed in the legislative process which led to the Recast Brussels I Regulation 2012,89 and has again recently been supported by a study commissioned by the European Parliament ${ }^{90}$ ). Rather than seek to achieve internationally harmonised rules, the EU could simply adopt unilateral rules designed to achieve unilaterally conceived policy goals. This is in fact already provided for under the jurisdictional rules relating to consumers and employees - in each case the rules under the Brussels I Regulation already apply regardless of the domicile of the defendant, ${ }^{91}$ and give weaker parties the right to sue and be sued in their 'home' state. The English courts have taken the view that these rules create jurisdictional rights for such parties, which should be enforceable against non-EU domiciled parties through issuing an anti-suit injunction to restrain proceedings brought in non-Member State courts. ${ }^{92}$ US employers of persons working in the EU are likely to find it troubling that they are unable to include enforceable US exclusive jurisdiction agreements in their employment $\operatorname{contracts}^{93}$ - the protection of employees in this way is an EU policy which is effectively projected on non-EU employers through unilaterally adopted jurisdictional rules.

If EU jurisdictional rules were unilaterally extended to non-Member State defendants more generally, the rules could be designed to achieve a range of objectives. They might, for example, also include provision for a forum of necessity rule - again as previously proposed by the European Commission ${ }^{94}$ (and adopted in the context of maintenance obligations ${ }^{95}$ ) - which could aim to ensure that claimants against non-Member State defendants had access to a court to pursue a remedy, if their rights have been breached in a foreign state without a functional or effective legal system. It is notable that the Commission proposed that at least some of the rules which should apply for claims

\footnotetext{
88 Pursuant to Article 18 of the Recast Brussels I Regulation 2012.

${ }^{89}$ See supra $\mathrm{n} 43$.

90 'Study: Possibility and terms for applying Brussels I Regulation (recast) to extra-EU disputes' (2014), supra n 76, at p.42.

${ }^{91}$ See Articles 18 and 21 of the Recast Brussels I Regulation 2012.

${ }^{2}$ See Samengo-Turner v J \& H Marsh \& McLennan (Services) Ltd [2007] EWCA Civ 723; Petter v EMC Europe Ltd [2015] EWCA Civ 828 and [2015] EWHC 1498 (QB).

93 Petter v EMC Europe Ltd [2015] EWCA Civ 828 and [2015] EWHC 1498 (QB).

${ }^{94}$ See supra $\mathrm{n} 44$.

${ }^{95}$ Council Regulation (EC) No 4/2009 of 18 December 2008 on jurisdiction, applicable law, recognition and enforcement of decisions and cooperation in matters relating to maintenance obligations, OJ L 7, 10 January 2009, Article 7.
} 
against non-EU domiciled parties - when the jurisdictional rules were having an external effect - should be different from those for claims against EU domiciled parties. This clearly recognises that different policy considerations apply in both contexts, and that the determination of appropriate jurisdictional authority might well also therefore be different.

The potential external impact of EU jurisdictional rules is, however, not limited to cases involving non-Member State defendants, which are currently (generally) regulated by national law. Cases involving defendants from a Member State may also have a potentially important external dimension. For example, a claim against a defendant domiciled in a Member State may concern immovable property in a non-Member State, ${ }^{96}$ or it may deal with matters covered by an exclusive jurisdiction agreement in favour of the courts of a non-Member State. In each case, the rules under the Brussels I Regulation purport to govern jurisdiction over the EU domiciled defendant, conferring jurisdiction on the courts of the Member State of their domicile as well as potentially other courts with subject matter connections to the dispute. ${ }^{97}$ However, the Brussels I Regulation rules are entirely silent on what significance, if any, should be attached to the types of considerations noted above. ${ }^{98}$ To put this another way, the scope of the rules is narrower than the scope of the Regulation, and thus the Regulation applies to a range of cases without being designed to do so. ${ }^{99}$ If a dispute concerns title to immovable property, the Regulation contains rules conferring exclusive jurisdiction on the courts of the location of the property if that property is located in a Member State, ${ }^{100}$ but does not deal with what should happen if the dispute concerns property located in a non-Member State. If a dispute is covered by an exclusive jurisdiction agreement in favour of the courts of a Member State, the Regulation determines what effect should be given to that agreement, ${ }^{101}$ but it does not deal with what should happen if the agreement confers jurisdiction on the courts of a non-Member State.

This is the well-known Owusu v Jackson ${ }^{102}$ problem under the Regulation - the rules were designed to deal exclusively with internal market problems, but they actually regulate a range of disputes which have connections going beyond the internal market. It remains unclear whether the Regulation may be given 'reflexive effect' to deal with these issues (applying some of its rules in relation to non-Member States in a similar way to which they are applicable between Member States), thereby projecting its policies externally, or whether jurisdiction under the Regulation is simply (and highly problematically)

\footnotetext{
96 The same argument applies in relation to any of the other matters dealt with as subject-matter exclusive jurisdiction under Article 24 of the Recast Brussels I Regulation 2012, such as disputes concerning the validity of registered intellectual property rights, or the validity of the decisions or constitution of a company.

${ }^{97}$ Pursuant to Articles 4 and 7 of the Recast Brussels I Regulation 2012.

${ }_{98}$ Note also the equivalent problem in the context of the recognition and enforcement of judgments, discussed supra n 25 .

${ }^{99}$ See further discussion in Mills (2013), supra n 41, at p.469.

100 Article 24(1).

101 Article 26.

102 Owusu v Jackson [2005] ECR I-1383, Case C-281/02. See generally Richard Fentiman, 'Civil Jurisdiction and Third States: Owusu and After' (2006) 43 Common Market Law Review 705; Adrian Briggs, 'The Death of Harrods: Forum Non Conveniens and the European Court' (2005) 121 Law Quarterly Review 535.
} 
unaffected by these concerns. ${ }^{103}$ The terms of the Recast Regulation arguably suggest the latter problematic conclusion, because they permit Member State courts to take into account non-Member State connections which would justify exclusive jurisdiction under the Regulation, but only if a Member State court is seised of a dispute already before the courts of a non-Member State ${ }^{104}$ - potentially implying that they could not take such matters into consideration if first seised. If this is the case, the Regulation rules have rather strange 'external' effects. They would require Member State courts, if first seised of a dispute, to exercise (almost certainly unenforceable) jurisdiction over disputes concerning title to non-Member State immovable property. They would also require Member State courts to exercise jurisdiction even if the parties have contracted to give exclusive jurisdiction to the courts of a non-Member State - thus effectively preventing Member State domiciled parties from entering into binding exclusive jurisdiction agreements in favour of non-Member State courts, and thereby potentially creating a significant international business disadvantage for EU based companies. ${ }^{105}$

This is perhaps the quintessential example of an exercise of internal market private international law regulation which has had problematic and at least largely unintended external effects. Another well known example is the fact that, as already noted above, judgments from one Member State are recognised and enforced in other Member States under the streamlined Brussels I Regulation rules, regardless of whether the judgment court took jurisdiction under the Regulation or under its national rules, and thus regardless of whether the judgment debtor has any connections to any Member State. This has the curious and perhaps unintended side effect that the traditional national rules of jurisdiction of the Member States which continue to apply to non-EU domiciled defendants, including a range of controversial 'exorbitant' jurisdictional rules, have been made more powerful under the Regulation (because judgments based on these rules can now be readily enforced throughout the EU), to the significant disadvantage (and apparent consternation) of non-EU domiciled parties. ${ }^{106}$ These examples highlight clearly the need to take into consideration the potential external consequences of internal exercises of competence in the field of private international law - since such exercises are likely to have external effects, those effects should at least be the product of conscious policy design rather than apparently unintended implication.

\section{Challenges}

Whenever private international law rules are adopted, attention must of course be paid to their content - what effects they will have, and whether they will advance relevant policy

\footnotetext{
103 See further eg Smith, Lasserson, and Rymkiewicz 'Reflections on Owusu: The Radical Decision in Ferrexpo' (2012) 8 Journal of Private International Law 389.

104 Pursuant to Recital 24.

105 At least one person involved in the negotiation of the Recast Regulation has argued (at a conference attended by the author) that this effect in relation to jurisdiction agreements is intentional, because it incentivises non-Member States to accede to the Hague Convention on Choice of Court Agreements, as only jurisdiction agreements in favour of the courts of Convention states will be given effect. If this is indeed the basis of the rule, there must be concerns about whether rendering important clauses of numerous commercial contracts unenforceable, and potentially disadvantaging a range of EU commercial actors in their external business activities, is an appropriate mechanism to use to pursue such a policy goal.

106 See supra n 26.
} 
goals. This is the case whether those goals are traditional private international law goals (such as the appropriate allocation of regulatory authority) or substantive policy goals (such as promoting environmental protection). While thus far the focus in the EU has been primarily on the effects of private international law as a matter of the internal market, attention should also be paid to consideration of what policy impact the rules might have internationally - both as a matter of existing rules (particularly in the case of the Rome I and II Regulations) and the possible extension of the rules to external contexts (particularly in the case of the Brussels I Regulation).

Focusing on the policy effects of private international law rules also presents an important challenge. Pursuing such goals through private international law is likely to make it more difficult to achieve other traditional private international law goals such as advancing decisional harmony (to reduce incentives for forum shopping), or minimising the risk of regulatory conflict between states. If private international law rules embody substantive policy values, there is less likelihood of reaching international agreement on those rules. Rules which promote substantive values are in fact also likely to favour certain parties in litigation (such as claimants in environmental cases, as discussed above), and thereby provide an incentive for forum shopping. An argument might thus well be made that substantive policy goals should not be pursued through private international law, because of the distorting effects that this has on the rules and their capacity to achieve other goals and values traditionally embodied in private international law.

These issues are difficult, and open to a range of possible positions. One option open to the EU would be to decide (now or at some point in the future) that international harmonisation efforts are too difficult, and that therefore the EU should pursue its own private international law rules unilaterally, focused on advancing its own policy interests. Another possible (and opposite) decision would be that international harmonisation must be pursued at all costs, because reaching agreement on the rules (and thereby reducing the risk of conflicting judgments) is more important than the actual content of the rules. An arguably better approach than either of these extremes would be to adopt an intermediate position - developing EU private international law rules with a focus on their policy impacts, but also participating in harmonisation efforts with the understanding that the benefits of harmonisation might ultimately require a degree of compromise when it comes to the content of the rules. Layered on top of each of these options is a further problem - whether it is better to have specialised rules dealing separately with internal market and international cases, or whether it is better for the sake of uniformity to have a single set of rules, even if this requires compromise in terms of their appropriateness and effectiveness in achieving desired policy goals.

A further issue which would arise if EU rules were unilaterally extended to apply to matters of private international law presently governed by national law (such as recognition of non-EU Member State judgments, or most cases concerning jurisdiction over non-EU domiciled defendants) would be consideration of what should happen where that national law was based on an existing treaty relationship. If a Member State currently has a treaty with a non-Member State providing for reciprocal enforcement of judgments, for example, that arrangement might potentially be in conflict with EU rules (if those EU rules are not based on a bilateral or regional agreement which would replace 
the prior bilateral arrangement as a matter of international obligation). Similar issues have, however, already been faced in the context of international investment law, and they have not proven impossible to manage in a pragmatic and sensible way. ${ }^{107}$ Reciprocal arrangements based on national legislation (rather than international commitments through treaties) would be even easier to override, as obligations conditional on reciprocity would fall away if national law were displaced by EU rules.

\section{B. Pursue regulatory objectives through private international law exceptions}

The second technique which might be pursued under the 'think global act local' approach is to use private international law exceptions (rather than rules) to achieve policy objectives. This is a related but distinct means of using private international law, which relies on the potential negative or blocking effects of private international law exceptions as a technique to give EU regulatory policies external effect.

\section{Goals}

Private international law rules generally reflect an openness to foreign law and legal practices, which might be described as a 'tolerance of difference'. ${ }^{108}$ Foreign law is applied even if it is different from local law, and foreign judgments are enforced even if they decide a case differently from the way in which a local court would have decided it. This general approach is, however, subject to important exceptions, particularly through the concept of public policy. ${ }^{109}$ All EU choice of law rules as well as the rules on the recognition and enforcement of judgments admit the possibility that the usual acceptance of foreign law and judgments may be overridden where it would be contrary to local public policy. ${ }^{110}$

The use of public policy and other similar defences to private international law rules is generally viewed as having a negative or blocking effect - it only prevents local enforcement of the judgment, or local application of the law. But in so doing, it may also potentially have the effect of projecting certain values or interests externally. If, for example, the EU were to refuse to enforce judgments from a particular state because of a particular problem with the organisation of the judicial system in that state (for example, leaving it vulnerable to political interference), that might put pressure on that state to address the problem. If EU member states were to refuse to apply a particular foreign law because it was identified as unjust, then that might also influence the foreign state to reform the law in such a way as to increase its effectiveness. This technique essentially relies on the fact that negative defences or exceptions to private international law rules

107 Regulation (EU) No 1219/2012 of the European Parliament and of the Council of 12 December 2012 establishing transitional arrangements for bilateral investment agreements between Member States and third countries, OJ L 351, 20.12.2012, p.40.

108 See generally Mills (2009), supra n 80, at p.5ff.

109 See generally Alex Mills, 'The Dimensions of Public Policy in Private International Law' (2008) 4 Journal of Private International Law 201.

110 See eg Recast Brussels I Regulation 2012, Article 45(1)(a); Rome I Regulation, Article 21; Rome II Regulation, Article 26. 
can be used as a means of leveraging foreign states to come into line with EU standards. By acting locally, to refuse certain foreign practices recognition in the EU, it is possible that EU values are projected globally, principally (although not exclusively) for the benefit of non-EU parties. This technique is in some ways the antithesis of multilateralism. Instead of prioritising harmonisation of private international law rules and the consequential achievement of decisional harmony, it relies on an assertion of local values to international cases, disrupting the usual operation of private international law.

Another way of understanding this is as a form of 'conditionality', a leveraged projection of power which is a well understood technique in other contexts. It is perhaps most famously associated with the IMF and World Bank, institutions which do not have the power to dictate economic policies applied by sovereign states, but do, however, have the power to attach conditions to loans which they may make to states. Their common practice is (or at least was) therefore to use those conditions as a means of effectively dictating state economic policies (pursuant to what became known as the 'Washington Consensus'), particular in relation to financially dependent or vulnerable states. ${ }^{111}$

The EU uses similar techniques itself in a range of circumstances, to project EU policies extraterritorially. ${ }^{112}$ For example, the EU provides enhanced access to European markets for goods which have been produced in states which have ratified and implemented certain international labour and environmental standards, as a deliberate means to incentivise developing states to comply with those standards. ${ }^{113}$ Similarly, the EU has considered requiring airlines whose flights use EU airports to comply with EU environmental regulations, even in relation to those parts of their flights which are not in the EU (unless regulated by other countries with rules providing equivalent environmental protection). ${ }^{114}$ Again similarly, the EU projects its regulatory influence to 'candidate countries' which are attempting or aspiring to meet the conditions of EU membership. In each of these contexts, the EU uses the possibility of (conditional) 'access' - to markets, airspace, or membership of the union - to project its regulatory power beyond its own territorial limits. (A further interesting variation may arguably be identified in the recent Schrems decision of the ECJ on Data Protection, where the court held that data could not be exported from the EU unless the recipient state would provide 'a level of protection of fundamental rights and freedoms that is essentially equivalent to that guaranteed within the European Union'115 - thus effectively making

\footnotetext{
111 See generally eg Carlos Santiso, 'Good Governance and Aid Effectiveness: The World Bank and Conditionality' (2001) 7 Georgetown Public Policy Review 1; Charles Gore, 'The Rise and Fall of the Washington Consensus as a Paradigm for Developing Countries' (2000) 28 World Development 789.

112 See generally Joanne Scott, 'Extraterritoriality and Territorial Extension in EU Law' (2014) 62 American Journal of Comparative Law 87; Joanne Scott, "The New EU "Extraterritoriality" (2014) 51 Common Market Law Review 1343.

113 Known as 'GSP+' - see further http://ec.europa.eu/trade/policy/countries-andregions/development/generalised-scheme-of-preferences/; http://trade.ec.europa.eu/doclib/press/index.cfm?id=1006.

114 The compatibility of these rules with public international law was challenged but upheld by the ECJ - see Air Transport Association of America (Reference for a preliminary ruling) [2011] EUECJ C-366/10. They have since been suspended to allow for negotiation of a possible global approach through the International Civil Aviation Organization, which is ongoing - see generally http://www.icao.int/Meetings/GLADs-2015/Pages/default.aspx. 115 Schrems [2015] EUECJ C 362/14 (6 October 2015).
} 
export of EU data conditional on the export of EU data protection standards.) Access to recognition through rules of private international law might thus be viewed as a further possible application of this technique. This would not require international harmonisation of private international law rules, but only an EU standardisation of private international law exceptions, such as a clearer formulation of a 'European' public policy. ${ }^{116}$

\section{Action}

There is an argument that elements of this approach, intentionally or otherwise, are already present in some existing practice in relation to private international law. For illustrations in this context, however, we have to turn to the European Court of Human Rights. This is because presently EU instruments such as the Brussels I Regulation only deal with the recognition and enforcement of judgments between Member States. EU law has thus not previously engaged with questions of what restrictions might apply to the recognition and enforcement of non-Member State judgments, although this might change in light of the development of the Charter of fundamental rights of the European Union. The European Court of Human Rights has, however, had occasion to consider the circumstances in which Convention states (including but not of course limited to Member States of the European Union) must refuse recognition of a judgment from a non-Convention state which violates the standards of the ECHR. In Pellegrini v Italy, ${ }^{117}$ the ECtHR held that the Italian courts were obliged to refuse recognition of a divorce judgment from the Vatican (a non-Convention state), obtained in violation of ECHR procedural fairness standards. The clear consequence is that Vatican divorce proceedings must follow ECHR procedures if they are to be given effect in Italy or any other Member State - which may well be necessary in many cases, for example if the proceedings have implications for the distribution of property located in any Member State. A nonConvention state may thus effectively be pressured or even forced, through the use of private international law exceptions, to comply with the Convention.

A less strict but still similar approach was followed in the earlier decision of Drozd and Janousek $v$ France and Spain, ${ }^{118}$ in which the court had to consider whether France could imprison (on behalf of Andorra) persons convicted of criminal offences in Andorra, if the procedures which had been followed in Andorra (a non-Convention state) were noncompliant with the Convention. The Court held that although 'the Convention does not require the Contracting Parties to impose its standards on third States or territories',119 Convention states 'are, however, obliged to refuse their co-operation if it emerges that the conviction is the result of a flagrant denial of justice'. ${ }^{120}$ It does not appear that the Court had in mind the external effects of adopting this policy in reaching this conclusion - but those effects are apparent. Since Andorra was dependent on the cooperation of France to house its prisoners, a finding that France could not cooperate with Andorra

\footnotetext{
116 See further Mills (2008), supra n 109, at p.214; Horatia Muir Watt, 'Evidence of an Emergent European Legal Culture: Public Policy Requirements of Procedural Fairness Under the Brussels and Lugano Conventions’ (2001) 36 Texas International Law Journal 539.

117 Pellegrini v Italy [2001] ECHR 480 (30882/96).

118 Drozd and Janousek v France and Spain (1992) 14 EHRR 745.

119 At [110].

${ }^{120}$ Ibid. An equivalent approach was followed by the House of Lords in USAv Montgomery (No 2) [2004] UKHL 37.
} 
because the procedures followed in Andorra constituted a flagrant denial of justice according to Convention standards would have necessitated a change in Andorran practices, almost certainly to bring them (at least closer) in line with Convention standards. Although, as the court noted, state parties to the Convention are not required 'to impose its standards on third States or territories', the effect of the ECtHR's decision is that such third states are likely, at least in some circumstances, to voluntarily adopt such standards in order to gain continued access to or cooperation with Convention states, thereby indirectly projecting the Convention standards extraterritorially.

This technique has also been (perhaps more deliberately) followed in the United Kingdom in one prominent instance - through the Protection of Trading Interest Act 1980. This Act provides that foreign civil judgments will not be enforced in the UK where the amount of damages obtained is calculated through a process of multiplication. The Act reflects dissatisfaction with a common practice in US civil proceedings, under which multiple (usually treble) damages may be awarded for 'flagrant' breaches of certain rules, such as tort or competition law. ${ }^{121}$ The Act does not, however, merely require UK courts to refuse recognition of multiplication effects - it requires the courts to refuse recognition of any part of a judgment which has been obtained through multiplication, and allows a defendant in US proceedings to recover in UK courts any noncompensatory part of the judgment which they have been forced to pay. The very clear intention of these rules is to frustrate and undermine US practice in awarding treble damages. Claimants in US proceedings against UK defendants, who know that they may have to enforce their judgment in the UK, are likely to ask the US court not to award treble damages, otherwise they will have an unenforceable judgment. Similarly, claimants bringing US proceedings against UK defendants, who themselves have assets in the UK, are likely not to ask for treble damages, because the UK defendant will simply be able to recover them in UK proceedings. The direct intended effect of these rules is therefore to change the practice of claimants in US courts, and thereby the practice of US courts themselves. ${ }^{122}$ By refusing to enforce a foreign judgment in the UK if the judgment has been obtained following certain procedures, the effect is to project the UK's disapproval of those procedures extraterritorially.

The possibility of a similar approach in the EU is perhaps hinted at in Recital 32 of the Rome II Regulation, which provides that:

[t]he application of a provision of the law designated by this Regulation which would have the effect of causing non-compensatory exemplary or punitive damages of an excessive nature to be awarded may, depending on the circumstances of the case and the legal order of the Member State of the court seised, be regarded as being contrary to the public policy (ordre public) of the forum.

121 See generally M.A. Blythe, 'The Extraterritorial Impact of the Anti-Trust Laws: Protecting British Trading Interests' (1983) 31 American Journal of Comparative Law 99; A V Lowe, 'Blocking Extraterritorial Jurisdiction: The British Protection of Trading Interests Act, 1980’ (1981) 75 American Journal of International Law 257.

122 See eg Fawcett and Carruthers (2008), supra n 19, at p.563. 
EU Member State courts are thereby invited to refuse to apply the law of non-Member States if it does not conform to this standard. If this is understood to inform public policy not only in the context of choice of law but also the recognition and enforcement of judgments, claimants in non-EU Member State proceedings against EU parties might well be likely to ask for non-compensatory damages not to be awarded, in order to ensure that their judgment is ultimately enforceable in the EU. The effect once again, if not the intention, would be the extraterritorial projection of a policy, through imposing conditions on access to the foreign law or judgment recognition rules of the EU. This technique could potentially be used to project a wide range of further policies extraterritorially in a similar way. The EU might, for example, mandate a refusal of recognition of foreign defamation judgements obtained under a law which does not meet minimum standards of free speech protection, rather like the approach adopted in the United States under the SPEECH Act 2010.123 To adopt this approach it would not be necessary for the EU to harmonise entirely the rules governing recognition and enforcement of non-Member State judgments, but only to establish a degree of 'Europeanisation' of public policy defences to the enforcement of such judgments, a process which has already taken place to some extent. ${ }^{124}$

\section{Challenges}

There are three principal concerns which might be raised concerning this technique. The first relates to its effectiveness. It is unclear whether, apart from in very narrow circumstances, foreign states will care sufficiently about whether their judgments are enforced or their laws applied in the courts of EU Member States for it to work. It is notable that the examples above concern the Vatican and Andorra, which depend on unusually close cooperation with EU Member States. Determining the influence of EU private international law on foreign substantive law reform would also be difficult to measure. Adopting this technique may end up achieving little or nothing - nevertheless, as examined above, it is analogous to techniques which the EU has used in other contexts.

The second concern relates to the negative consequences of adopting this technique. A refusal to recognise foreign laws or judgments, because they are contrary to certain defined local policies or values, is clearly in tension with other objectives of private international law. It is, for example, evidently not consistent with principles of decisional harmony, of reducing incentives for forum shopping, or avoiding the risk of conflicting judgments. For it to work, it relies on establishing a disharmony between the local and foreign treatment of these issues, which is clearly in tension with the traditional objectives of private international law. This could not only undermine those objectives, but could be a source of serious inconvenience and perhaps even injustice to private parties. Equally, if

12328 USC 4102-5. This Act, however, controversially relies on the US First Amendment to define this minimum standard: see Mills (2008), supra n 109; Mark D. Rosen, 'The SPEECH Act's Unfortunate Parochialism: Of Libel Tourism and Legitimate Pluralism' (2012) 53 Virginia Journal of International Law 99.

${ }^{124}$ See eg Mills (2009), supra n 80 at p.190ff; Mills (2008), supra n 109; HP Meidanis, 'Public Policy and Ordre Public in the Private International Law of the EU: Traditional Positions and Modern Trends' (2005) 30 European Law Review 95; Horatia Muir Watt, 'Evidence of an Emergent European Legal Culture: Public Policy Requirements of Procedural Fairness Under the Brussels and Lugano Conventions’ (2001) 36 Texas International Law Journal 539. 
private international law rules were adopted unilaterally to pursue substantive policy objectives, as discussed above, applying exceptions to those rules too readily would risk undermining the EU's own policy goals. These concerns could be addressed to some extent through an attenuated application of public policy concerns - for example, only refusing recognition of a non-Member State judgment where it involves a 'flagrant' violation of an ECHR right (the approach adopted in Drozd and Janousek) - but such attenuation would also be likely to reduce the effectiveness of the technique itself.

A third concern with this technique relates to its legitimacy. If private international law rules could effectively be used to leverage other states to comply with EU policies, this technique is unlikely to be viewed favourably by states who become subject to such pressure. Indeed, the EU's adoption of such a technique in the context of environmental regulation of air traffic has been highly controversial, ${ }^{125}$ as has the technique of 'conditionality' adopted by institutions such as the IMF and WTO. ${ }^{126}$ While this approach does not formally amount to an impermissible extraterritorial exercise of jurisdiction, it is clear that it endeavours to achieve an equivalent effect, and more cooperative means of addressing the relevant policy goals may be just as effective without the accompanying risk of perceived regulatory over-reach.

\section{Conclusions}

The four techniques analysed above are each distinct possibilities for an EU private international law 'foreign policy'. The first two rely on the exercise of external competence by the EU to advance (primarily) internal interests - thinking locally and acting globally - while the second two rely on the exercise of internal competence to advance (primarily) external interests - thinking globally and acting locally. Each represents a different way in which private international law may be used 'externally' by the EU to effect certain policies, revealing a variety of potential purposes for private international law. As a case study, this article also presents these as legal techniques which might be used by other actors and in other fields.

Each of these techniques has advantages and disadvantages, and determining which approach or approaches should be adopted is itself a difficult policy question. Pursuing multilateral harmonisation would have the greatest benefits in terms of the traditional objectives of private international law - reducing incentives for forum shopping through advancing decisional harmony, and reducing the risk of conflicting judgments. The EU is already playing a significant role in the Hague Conference on Private International Law, and however difficult it may be, the payoffs for achieving international harmonisation of private international law rules would be very significant. Pursuing regional or bilateral harmonisation would address similar policy concerns in a potentially more achievable

\footnotetext{
125 See supra n 114; see further eg Lauren E Mullen, 'The European Union Overstepping its Bounds and Borders: The Extraterritorial Effect of the Emissions Trading System and its Call for Multilateral Action' (2013) 74 University of Pittsburgh Law Review 783; Brian F. Havel and John Q. Mulligan, 'The Triumph of Politics: Reflections on the Judgment of the Court of Justice of the European Union Validating the Inclusion of Non-EU Airlines in the Emissions Trading Scheme' (2012) 37 Air and Space Law 3.

126 See supra $\mathrm{n} 111$.
} 
way, but with diminished benefits and greater associated risks. Pursuing substantive policies through private international law rules could advance other values and would not depend on (although might benefit from) international cooperation, but could undermine traditional private international law goals. Pursuing substantive policies through private international law exceptions could similarly have other benefits, but the effectiveness of this approach may be doubted, and it would again come at a cost in terms of the traditional values and policies embodied in private international law rules.

It is not essential that only one technique be chosen, either for all EU private international law, or for a component of EU private international law (such as jurisdiction, or choice of law), or even for a single EU Regulation. While these different techniques are in various ways in tension with one another, more than one might be pursued simultaneously in a way which compromises and balances the different policy interests. What is, however, essential is that the EU's approach to private international law reflects a calculated and coherent analysis of these different policy considerations this could perhaps be undertaken as part of preparing the successor to the Stockholm Programme, which sets EU policy priorities in the development of an 'area of freedom, security and justice'. ${ }^{127}$ Under existing private international law rules, it appears that in a number of situations the focus has been so heavily on regulating the internal market that the external effects of the policy decisions which have been made are merely incidental. As the EU has now apparently gained exclusive external competence in the field of private international law, at least within those fields in which it has internal competence, greater consideration should be given to the potential external as well as internal policy benefits and costs of local or global action in the field of private international law. 